\title{
Correction to: Is psychosis a multisystem disorder? A meta-review of central nervous system, immune, cardiometabolic, and endocrine alterations in first-episode psychosis and perspective on potential models
}

\author{
Toby Pillinger ${ }^{1} \cdot$ Enrico D'Ambrosio $\mathbb{1}^{1} \cdot$ Robert McCutcheon $\mathbb{( I D}^{1} \cdot$ Oliver D. Howes ${ }^{1,2,3}$
}

Published online: 18 October 2018

(c) The Author(s) 2018. This article is published with open access

Correction to: Mol Psychiatry; https://doi.org/10.1038/ s41380-018-0058-9; published online: 9 May 2018

This article was originally published under standard licence, but has now been made available under a [CC BY 4.0] license. The PDF and HTML versions of the paper have been modified accordingly.

Open Access This article is licensed under a Creative Commons Attribution 4.0 International License, which permits use, sharing, adaptation, distribution and reproduction in any medium or format, as long as you give appropriate credit to the original author(s) and the source, provide a link to the Creative Commons license, and indicate if changes were made. The images or other third party material in this article are included in the article's Creative Commons license, unless indicated otherwise in a credit line to the material. If material is not included in the article's Creative Commons license and your intended use is not permitted by statutory regulation or exceeds the permitted use, you will need to obtain permission directly from the copyright holder. To view a copy of this license, visit http://creativecommons. org/licenses/by/4.0/.
Oliver D. Howes

oliver.howes@kcl.ac.uk

1 IoPPN, King's College London, De Crespigny Park, London SE5 $8 \mathrm{AF}, \mathrm{UK}$

2 MRC London Institute of Medical Sciences (LMS), Du Cane Road, London W12 0NN, UK

3 Institute of Clinical Sciences (ICS), Faculty of Medicine, Imperial College London, Du Cane Road, London W12 0NN, UK 